\title{
Effect of Price Changes on the Supply Response of Rubber in Nigeria (1980-2010)
}

\author{
${ }^{1}$ Agbogo, Elias A. and ${ }^{2}$ Aja Okorie \\ ${ }^{I}$ Department of Agricultural Economics/Extension Cross River University of Technology, Cross River State, \\ Nigeria \\ ${ }^{2}$ Department of Agricultural Economics, Management and Extension Ebonyi State University, Abakaliki, Ebonyi
}

State, Nigeria

\begin{abstract}
The study on the effect of price changes on rubber supply in Nigeria was carried out through the application of the Nerlovian partial adjustment model. Time series data covering a period of 30 years were obtained from the National Bureau of Statistics, Central Bank of Nigeria (CBN) Annual Agricultural Survey and the Central Bank of Nigeria Statistical Bulletin. The Nerlovian model was specified on the basis of the functional relationship between rubber supply and the lagged endogenous variables of rubber supply as well as the export price of rubber for the period under review. The findings revealed that previous year's output used as a lagged endogenous variable had a positive magnitude of 0.768 and was significant at $1 \%$. The positive sign and the proof of significance is consistent with economic theory which posits that output has a direct relationship with the previous production level. The magnitude of the export price co-efficient of 0.0012 was low and not significant. Though the sign is in line with theoretical expectation, the low value may be attributable to the spurious nature of the estimates of time series due to trending effect. The coefficient of determination $\left(R^{2}\right)$ of $76.4 \%$ indicates the proportion of the variation in natural rubber supply that was explained by the specified model. Also the Durbin Watson statistic value of 2.24 showed the presence of low autocorrelation. It is therefore recommended that an appropriate mechanism for price stabilization be instituted by governments as means of enhancing high export trade volume, since price is found to be a major determinant of rubber export trade in Nigeria.
\end{abstract}

Keywards: Price changes, Supply Response, Nigeria

\section{Introduction}

Coffee, rubber, cocoa, oil palm, kola nut and citrus constitute the bulk of perennial crops that are characterized by harvesting process which follows an inverted U-shape $(\cap)$. That is, there is low yield during the early years, followed by maximum yield in the middle years and low yield in the later years [1]. Naturally, the yield may vary with the time of planting, the fertility of the soil and the technological inputs. It may be possible to model the production of a perennial crop like rubber through investment decision processes whereby one may have to weigh present and future incomes as well as tradeoffs between a set value and change in income. Rubber farmers calculations involve whether postponing of replanting and continuing tapping will be more profitable than investing in new trees now [2]. He further stated that the decision rule would be to postpone any shift in operation when income is higher than the interest over the net present value. However, the problem here is while income is almost certain, interest over the net present value may not be sustained. Some farmers may decide against planting rubber because they have envisaged other profitable crops to grow in the early years to come, while other farmers may be more interested about their future position; whichever decision to be taken will depend perhaps on the age of the decision makers themselves because older farmers are less likely to place high value on future expected income than younger farmers. Apart from the trade-off between future and present income, there may also be a trade-off between asset value and change in income because it is known that the net present value of tree grown should be higher than other feasible investment alternatives [3]. It is also worthy of note that a farmer with particular skills and other endowments may prefer investing in annual crops even if the land is suitable for other crops or if the climate and marketing opportunities are favourable to other crops. The foregoing issues however suggest that the economics of perennial crop supply is rather complicated and can be approached from different angles. In all the approaches, the past, present and future product prices of the crop play a crucial role in the decision to remove, replant, plant a new crop or increase the acreage. An increase in the use of inputs which invariably leads to an increase in the output of a commodity may occur as a result of either an increase in the price of the product or a decrease in the price of inputs.

The supply response concept is based on the hypothesis that when the price of a product changes, there are likely to be correlated changes in the supply shifts. In particular, when product prices increase, new techniques of production are likely to be introduced [4]. This position presupposes a backlog of new technologies that may be adopted by producers of agricultural products. Under rising prices, firms may be 
induced to adopt new techniques at a somewhat faster rate and under such circumstances, an increase in output price can be expected to have two effects viz: cause farmers to increase output along the static supply curve and lead to shifts to new supply curves [5]. This is because once these mechanisms are adopted, improved production practices usually are retained even thought the price of the product subsequently declines. Favourable or unfavourable agricultural prices obviously can have a marked influence on the rate at which a new technology is adopted, and hence on the rate of change of farm output because farmers must have an incentive to use new techniques and access to sufficient capital to make the necessary investments [6].

\section{Materials and Methods}

The Federal Republic of Nigeria constitutes the study area. Nigeria lies on the Atlantic Coast of Central Africa and is bordered by Niger Republic and Chad to the north, Benin Republic to the east, Togo to the west and Cameroon to the south. The country covers a total land area of $923,678 \mathrm{~km}^{2}$. The proportion of the land use area out of the total land mass is made up of $15.7 \%$ of forest, $43.9 \%$ of pasture, $35.9 \%$ of agriculture and $4.5 \%$ of others. Nigeria's geography is diverse, with a wide range of climatic variations and corresponding variations in vegetations. The arid plains in the north give way to savanna in the central hills and plateau, merging into tropical rain forests in the southern lowlands and mountains to the south-east.

Nigeria has an estimated population of 150 million inhabitants based on the 2006 National Population Census exercise, and this puts it ahead of all other countries in Africa in terms of population. It is made up of three large ethnic groups - the Hausa - Fulani, Yoruba and Igbo [7]. The Muslim Hausa-Fulani live in the north of the country and maintain ancient ties with the Arab world. The Yoruba are mainly in the west, and have an elaborate political and religious system with trading networks across the West African coast, while the egalitarian Igbo ethnic group is in the south-east. These three major ethnic groups represent $70 \%$ of the population, while another $10 \%$ comprises of several other groups numbering more than 1 million each, including the Kanuri, Tiv and Ibibio. More than 300 smaller ethnic groups account for the remaining $20 \%$ of the population. However, these groups are similar in nature, thus fuse all strands of boundaries to become a huge group. This accounts for why most Nigerians speak more than one language [7].

The climate of Nigeria is tropical in nature, and it is occasionally subjected to variations, depending on the rainfall. There are two main seasons - the rainy and the dry seasons. During the rainy season, there is a high amount of rainfall especially within the southern part of the country which usually spans from about March to December, while in the north, rain starts at about May and ends in November. The dry season lasts for only about two months (January and February) and five months (December to April) in the south and north respectively. Temperatures are reasonably high throughout the year, averaging from $25^{\circ}$ to $28^{\circ} \mathrm{C}$. In the higher elevations of Jos Plateau, temperature is usually at an average of $22^{\circ} \mathrm{C}$, while the northern part of the country experiences greater temperature extremes. The country is made up of 36 states including Abuja, the Federal Capital Territory with a total of 774 Local Government Areas.

Before the discovery of crude oil, agriculture was the mainstay of the Nigerian economy. Even today, the agricultural sector provides employment for about $70 \%$ of the nation's population [8]. The country has good agricultural land covering a wide range of agro-ecological zones thereby, allowing for diverse crop and livestock production. The dry northern savanna is suitable for growing sorghum, millet, maize, rice, groundnut, cowpea, citrus, ginger, onions, tomato and cotton as well as the principal livestock-raising area in the country. In the middle belt and the south, the main crops are cassava, yam, plantain, maize and sorghum, cola nut, potato and ofcourse rice which is grown in the low-lying flooded areas. The main cash crops in the south are oil palm, cocoa, cola nut and rubber. Although, other cash crops could be found across the entire south, rubber is largely grown only in eight states namely: Cross River, Edo, Delta, Ogun, Ondo, Imo, Abia and Akwa Ibom.

\subsection{Sources of Data}

Data for the study were obtained from secondary sources (time series data). Sources used included National Bureau of Statistics (NBS), Central Bank of Nigeria (CBN) Annual Agricultural Survey and Central Bank of Nigeria (CBN) Statistical Bulletin. Time series data were collected on the yearly exported processed rubber (tons) for thirty years (1980-2010). Data were also obtained for yearly prices (both local and export) of processed rubber products - ribbed smoked sheets (RSS) series, money market interest rate (\%) and the average of the annual exchange rate of the Naira to the United State's Dollar within the period under review.

\subsection{Model Specification}

The effect of price changes was addressed by the Nerlovian adjustment model. The Nerlovian adjustment model is based on the fact that there is a derived level of output in period t say $Y_{t}$, which is dependent on price $P_{t}$ in period $t$. This can be expressed as:

$$
\mathrm{Y}_{t}^{*}=\mathrm{b}_{0}+\mathrm{b}_{1} \mathrm{P}_{\mathrm{t}}+\mathrm{U}_{\mathrm{t}}
$$


where

$$
\begin{aligned}
& \mathrm{Y}_{t}^{*}=\text { supply quantity }(\mathrm{kg}) ; \\
& \mathrm{P}_{\mathrm{t}}=\text { price in period } \mathrm{t}(\mathrm{N}) ; \\
& \mathrm{U}_{\mathrm{t}}=\text { the stochastic term; } \\
& \mathrm{b}_{0}=\text { the intercept; and } \\
& \mathrm{b}_{1}=\text { co-efficient of price. }
\end{aligned}
$$

Due to the gestation period involved in all investments, the actual or realized change in output in any one period is only a fraction of the desired change. Therefore, the adjustment is gradual due to technological, financial or administrative/management constraints. This can be expressed as:

$$
\mathrm{Y}_{\mathrm{t}}-\mathrm{Y}_{\mathrm{t}-1}=\beta\left(\mathrm{Y}_{t}^{*}-\mathrm{Y}_{\mathrm{t}-1}\right)+\mathrm{Vt}
$$

where $0<\beta<1$

$\mathrm{Y}_{\mathrm{t}}-\mathrm{Y}_{\mathrm{t}-1}=$ actual change in output $(\mathrm{kg})$

$\mathrm{Y}_{t}^{*}-\mathrm{Y}_{\mathrm{t}-1}=$ the desired change in output in period $\mathrm{t}(\mathrm{kg})$ and

$\beta=$ adjustment co-effiecient.

Equation (2) above implies that the actual output change in any period $\left(\mathrm{Y}_{\mathrm{t}}-\mathrm{Y}_{\mathrm{t}-1}\right)$ is only a fraction of the desired change $\left(\mathrm{Y}_{t}^{*}-\mathrm{Y}_{\mathrm{t}-1}\right)$. By substituting (1) in (2), we have

$$
\mathrm{y}_{\mathrm{t}}-\mathrm{Y}_{\mathrm{t}-1}=\left[\beta\left(\mathrm{b}_{0}+\mathrm{b}_{1} \mathrm{P}_{1}+\mathrm{U}_{\mathrm{t}}\right)-\mathrm{Y}_{\mathrm{t}-1}\right]+\mathrm{V}_{\mathrm{t}}
$$

by solving for $Y_{t}$, we have

$$
\mathrm{Y}_{\mathrm{t}}=\mathrm{b}_{0} \beta+\mathrm{b}_{1} \beta \mathrm{P}_{\mathrm{t}}+(1-\beta) \mathrm{Y}_{\mathrm{t}-1}+\left(\beta \mathrm{U}_{\mathrm{t}}+\mathrm{V}_{\mathrm{t}}\right)
$$

\begin{tabular}{|c|c|c|c|c|}
\hline Variable & Coefficient & Std Error t-statistic & Prob. Level & \\
\hline Constant & 54.5160 & 23.7964 & 2.2909 & 0.0307 \\
\hline $\mathrm{Y}_{\mathrm{t}-1}$ & 0.7689 & 0.1167 & $6.5855 *$ & 0.0000 \\
\hline $\mathrm{p}_{\mathrm{t}}$ & 0.00012 & 0.0001 & 0.9778 & 0.3375 \\
\hline
\end{tabular}

Equation (4) means that the output in any one period t depends partly on the price level in that period and partly on the output in the last period; if $\beta=1$, then the adjustment is instantaneous (getting what you want instantly).

\section{Results and Discussion}

The effect of price changes on the supply of rubber was examined through the application of the Nerlovian Model specified in equation 1. The results obtained from this specification are presented in table 1 below.

Table 1: Regression Estimates of the Nerlovian Model

Source: Computed from E-views 7 results.

The results for the functional relationship between export rubber supply and the lagged endogenous variable of export rubber supply as well as the export price are presented in table 1 above within the context of the partial adjustment model (Nerlovian model). The results showed that the lagged endogenous variable had a positive magnitude of 0.7689 and was significant at $1 \%$, while the export price also had a positive magnitude of 0.0012 and was not significant. The coefficient of determination for the model $\left(\mathrm{R}^{2}\right)$ was 0.764 or $76.4 \%$, the Fstatistic was 40.49 , while the corresponding Durbin-Watson statistic was 2.24 . The implication of these results is that the knowledge of the previous year's rubber supply level had a significantly positive effect on the quantity of rubber supplied in the current year.

Though the magnitude of the coefficient of export price of 0.0012 was low, the positive sign is in consonance with the a priori expectation of a direct relationship between price and quantity supplied of a commodity. The $\mathrm{R}^{2}$ value of $76.4 \%$ implies that $76.4 \%$ of the variation in the endogenous variable (rubber supply) was explained by the specified model. In other words, the degree to which the specified model is best fitted was accounted for by a high $\mathrm{R}^{2}$ value. Also, the DW statistic value of 2.24 implies that there was low autocorrelation among the exogenous variables. This finding is in accordance with the opinion of Metha and Metha (1994) who reported that any DW value greater than 2 indicates low level of autocorrelation among the specified exogenous variables in a given model.

\section{Conclusion and Recommendations}

The implication of these findings is that the previous year's rubber supply has significant effect on a present year's level of rubber supply. This result collaborates with the findings of [9] who discovered in his study of aggregate supply response of perennial crops in developing countries that the present year's level of 
supply quantity has a direct link with the previous production level. He further contended that the link is essentially through the price expectation of farmers based on the previous years prices often offered.

While the lagged endogenous variable is significantly related to a present output level, the export price had a positive magnitude of 0.00012 and was not significant. However, the positive sign is in line with the theoretical foundation that price has a positive relationship with supply quantity. This unexpected nonsignificant relationship exhibited by the export price variable may be attributable to the spurious nature of the estimators of time series due to the trending effect. These findings are similar to those of [10] who found that long-run export price of rubber showed positive relationship with rubber supply. It is therefore recommended that measures aimed at providing for an appreciable level of the naira to other foreign currencies should be encouraged as this will provide price incentive for local rubber exporters as well as the producers who may take advantage of a favourable market environment. Also, since the volume of export trade is dependent on the capacity utilization of associated facilities, government should provide the much needed infrastructural facilities to allow for smooth trade operations in the rubber industry.

\section{References}

[1]. A. Kidane, An analysis of agricultural supply response in Ethiopia: the case of perennial crops Asmara AERC research paper 99, African Economic Research Consortium, Nairobi, 2007, 1-15

[2]. K. Burger, The economics of perennial crop supply: Modeling the Indian rubber economy. Indian Journal of Economics 4(7), 2004,3-31

[3]. B. C. French, and G. A. King, Planting and removal relationships for perennial crops: An application of cling peaches. American Journal of Economics 67(2), 1985, 215-223.

[4]. M. Nerlove, Expectations, plan and realizations in theory and practice. Econometrica. 51(5), 1983, $249-278$.

[5]. W. B. Trail, D. Colman and T. Young, Estimating irreversible supply functions. American Journal of Agricultural Economics 60(3), 1994, 403-421.

[6]. A. Rayner, The demand for inputs and the aggregate supply function for agriculture. Journal of Agricultural Economics. 21(2), 1997, 225-238.

[7]. M.K. Barbour, S. J. Oguntoyinbo, J.O Onyemelukwe, and J. C. Nwafor. Nigeria in maps ( Ibadan, Nigeria Publishers Ltd, 1982), 2-47.

[8]. O. O. Akanji and E.U. Ukeje, A review and analysis of agricultural prices in Nigeria. Central Bank of Nigeria Economic and Financial Review. 33(4), 1995, 35-61

[9]. R. Thiele, Estimating the aggregate supply response: A survey of techniques and results for developing countries. Kiel Institute of World Economics. Workshop paper No.1016, Kiel, 2000, 6-15.

[10]. C. S. Mesik., D. Y. Giroh and O. E. Owie, Analyzing the effect of trade liberalization policy in Nigeria rubber industry. Journal ofAgriculture and Social Sciences. Mumbai. 4(3), 2008, 130-134. 